\title{
Characteristics of tectonic activity phases along The Cao Bang - Tien Yen fault zone, Tien Yen - Lang Son section, Northeastern part, Vietnam
}

\author{
Truong Thanh Phi ${ }^{1}$ \\ Renat B. Shakirov*2 \\ Nadezhda S. Syrbu**2
}

\author{
${ }^{1}$ Hanoi University of Natural Resourses and Environment, Vietnam \\ ${ }^{2}$ V.I. Il'ichev Pacific Oceanological Institute, FEB RAS, Vladivostok, \\ Russia \\ *E-mail: ren@poi.dvo.ru \\ **E-mail:syrbu@poi.dvo.ru
}

\begin{abstract}
Peфepat PDF RuS
The Cao Bang - Tien Yen (CB-TY) fault zone, Tien Yen - Lang Son (TY-LS) section is about $100 \mathrm{~km}$ long, running in the NW-SE direction, the northeastern part of the Red River fault zone. The field survey is conducted at 21 locations, including the description of lithological characteristics, fracture orientation measurement, stratigraphic displacement, and the evidence of striation motion on the fault surface. The analytical results of 59 striations on the fault surface along the CB-TY fault zone, TY-LS section identified that the lateral strike-slip stress states with the four compression phases E-W, NE-SW, NW-SE and N-S. From evidences obtained in the field, together with the comparison of previous studies, the main tectonic phases are arranged in the order of directions: 1) NW-SE; 2) EW; 3) NE-SW and 4) N-S. In particular, the first compression phase of the NW-SE direction severely destroyed the old rocks of the Jurassic age and earlier, encountered at many survey locations along the CB-TY fault zone, TY-LS section; the second compression phase of the E-W direction occurred during the Cenozoic period, caused the left displacement of the Red River fault zone in the OligoceneMiocene period and the left motion along the CB-TY fault zone formed the Neogen sedimentary basins: Cao Bang, That Khe, Lang Son, Na Duong; the third compression phase of NE-SW direction occurred during the Mid-Late Miocene, caused a tectonic inversion of the NW-SE faults in the northern part of the Red River basin, which are located in the southeast area of the CB-TY fault zone; the final compression phase of the N-S direction, occurred during the Pliocene - Quaternary period, caused the right motion along the CB-TY fault zone and the Red River fault zone.
\end{abstract}

\section{Keywords}

CB-TY fault zone, Red River fault zone, Cao Bang basin, Neogene Na Duong basin, TY-LS section, thermal springs

For citation: Truong Thanh Phi, Shakirov R.B., Syrbu N.S. Characteristics of tectonic activity phases along The Cao Bang - Tien Yen fault zone, Tien Yen - Lang Son section, Northeastern part, Vietnam. Geosystems of Transition Zones, 2019, vol. 3, no. 4, pp. 345-363. (In English, abstract in Russian) https://doi.org/10.30730/2541-8912.2019.3.4.345-363

Для цитирования: Чон Тхань Фи, Шакиров Р.Б., Сырбу Н.С. Характеристики фаз тектонической активности вдоль зоны разлома Цхао Банг - Ти Иен, разрез Ти Иен - Ланг Сон, северо-восточная часть, Вьетнам. Геосистемы переходных зон. 2019. Т. 3, № 4. С. 345-363. (На англ. языке, реферат на русском) https://doi.org/10.30730/2541-8912.2019.3.4.345-363 


\section{References}

1. Böhme M., Prieto J., Schneider S., Nguyen Viet Hung, Do Duc Quang, Dang Ngoc Tran. 2011. The Cenozoic on-shore basins of Northern Vietnam: Biostratigraphy, vertebrate and invertebrate faunas. Journal of Asian Earth Sciences. 40(2): 672-687. https://doi.org/10.1016/j.jseaes.2010.11.002

2. Böhme M., Aiglstorfer M., Antoine Pierre-Olivier, Appel E., Havlik Ph., Metais G., Laq The Phuc, Schneider S., Setzer F., Tapper R., Dang Ngoc Tran, Uhl D., Prieto J. 2013. Na Duong (northern Vietnam) - an exceptional window into Eocene ecosystems from Southeast Asia. Zitteliana. A 53: 120-167.

3. Drogue C., Cat N.N., Dazy J. 2000. Geological factors affecting the chemical characteristics of the thermal waters of the carbonate karstified aquifers of Northern Vietnam. Hydrology and Earth System Sciences. 4(2): 332-340. https://doi.org/10.5194/hess-4-332-2000

4. Huchon P., Le Pishon X., Rangin C. 1994. Indochina Peninsula and the collision of India and Eurasia. Geology. 22(1): 27-30. https://doi.org/10.1130/0091-7613(1994)022<0027:ipatco>2.3.co;2

5. Kasatkin S.A., Golozubov V.V., Phung Van Phach, Le Duc Anh. 2014. Evidences of Cenozoic strike-slip dislocations of the Red River Fault System in Paleozoic Carbonate Strata of Cat Ba Island (Northern Vietnam). Russian Journal of Pacific Geology. 8(3): 163-176.

6. Lacassin P., Tapponnier H., Leloup Ph., Phan Trong Trinh, Nguyen Trong Yem. 1994. Morphotectonic evidence for active movement along the Red River Fault System. In: Proceed. Inter. Seis. Haz. South. Asia, p. 66-71.

7. Le Trieu Viet. 2004. Structural characteristics and evolution history of Cenozoic basins along Cao Bang-Tien Yen Fault Zone. Vietnam Journal of Earth Sciences. 26: 633-641.

8. Leloup P.H., Lacassin R., Tapponnier P., Schärer U., Dalai Z., Xiaohan L., Liangshang Z., Trinh P.T. 1995. The Ailao Shan-Red River shear zone (Yunnan, China), Tertiary transform boundary of Indochina. Tectonophysics. 251(1-4): 3-84. https://doi.org/10.1016/0040-1951(95)00070-4

9. Marett R.E., Allmendinger R.W. 1990. Kinematic analysis of fault-slip data. Journal of Structural Geology. 12: 973-986. https://doi.org/10.1016/0191-8141(90)90093-e

10. Michael B.W.F., Phung Van Phach. 2015. Late Neogene structural inversion around the northern Gulf of Tonkin, Vietnam: Effects from right-lateral displacement across the Red River fault zone. Tectonics. 34(2): 290-212. https://doi.org/10.1002/2014TC003674

11. Nguyen Giang Vu. 2003. Structural evolution of the block 102 and 106 Song Hong basin-implication for hydrocarbon potential. In: Proceedings of conference on "Vietnam petroleum institute: 25 years of development and achievements", p. 284-309. (In Vietnamese)

12. Nguyen Thac Cuong, Giang Cao Duy, Thang Tran Trong. 2005. General evaluation of the geothermal potential in Vietnam and the prospect of development in the near future. In: Proceedings World Geothermal Congress. Antalya, Turkey.

13. Nguyen Quoc Cuong, Tokarski A.K., S'wierczewska A., Zuchiewicz W.A., Yêm Nguyen Trong. 2013. Late Tertiary tectonics of the Red River Fault Zone: Structural evolution of sedimentary rocks. Journal of Geodynamics. 69: 31-53. https://doi.org/10.1016/j.jog.2012.05.002

14. Phan Dong Pha, Geptner A.R., Nguyen Xuan Huyen, Petrova V.V., Le Thi Nghing, Nguyen Minh Quang. 2011. A new discovery of stromatolite fossil in sediments of the Rinh Chua formation, Na Duong basin, Lang Son, Vietnam. Vietnam Journal of Earth Sciences. 33(1): 94-96. https://doi.org/10.15625/0866-7187/33/1/282

15. Phan Trong Trinh, Ngo Van Liem, Nguyen Van Huong, Hoang Quang Vinh, Bui Van Thom, Bui Thi Thao, Mai Thanh Tan, Nguyen Hoang. 2012. Late Quaternary tectonics and seismotectonics along the Red River Fault System, North Vietnam. Earth-Science Reviews. 114(3-4): 224-235. https://doi.org/10.1016/j.earscirev.2012.06.008

16. Pubellier M., Rangin C., Phach P.V., Que B.C., Hung D.T., Lung Sang C.L. 2003. The Cao Bang-Tien Yen Fault: implications on the relationships between the Red River Fault and the south China Coastal Belt. Advances in Natural Sciences. 4(4): 347-361.

17. Rangin C., Klein M., Roques D., Le Pishon X., Trong L.V. 1995. The Red River Fault System in the Tonkin Gulf, Vietnam. Tectonophysics. 243(3-4): 209-222. https://doi.org/10.1016/0040-1951(94)00207-p

18. Sun Z., Zhou D., Zhong Z., Zeng Z., Wu S. 2003. Experimental evidence for the dynamics of the formation of the Yinggehai basin, NW South China Sea. Tectonophysics. 372(1-2): 41-58. https://doi.org/10.1016/s00401951(03)00230-0

19. Tapponnier P., Peltzer G., Armijo R. 1986. On the mechanics of the collision between India and Asia. Geological Society of London, Special Publications. 19(1): 113-157. https://doi.org/10.1144/gsl.sp.1986.019.01.07

20. Tapponnier P., Lacassin R., Leloup P.H., Schärer U., Dalai Z., Xiaohan L., Liangshang Z., Jiayou Z. 1990. The Ailao Shan/Red River metamorphic belt: Tertiary left-lateral shear between Indochina and South China. Nature. 343(6257): 431-437. https://doi.org/10.1038/343431a0

21. Vu Van Chinh. 2002. Neotectonic development phases and mechanism of the Cao Bang-Tien Yen Fault. Journal of Earth Sciences. 22(3): 181-187. (In Vietnamese).

22. Wysocka A. 2009. Sedimentary environments of the Neogene basins associated with the Cao Bang-Tien Yen Fault, NE Vietnam. Acta Geologica Polonica. 59: 45-69. 
23. Zuchiewicz W., Cuong Nguyen Quoc, Zasadni J., Yêm Nguyen Trong. 2013. Late Cenozoic tectonics of the Red River Fault System, Vietnam, in the light of geomorphic studies. Journal of Geodynamics. 69: 11-30. https://doi.org/10.1016/j.jog.2011.10.008 